УДК 37.09(477.83)

DOI 10.24919/2519-058x.4.111466

Микола ГАЛІВ, orcid.org/ 0000-0001-7068-3124

кандидат педагогічних наук, дочент, дочент кафедри історії України Дрогобицького державного педагогічного університету імені Івана Франка (Україна, Дрогобич) halivm@yahoo.com

Уляна ГАЛІВ, orcid.org/ 0000-0002-8511-1484 кандидат філологічних наук, дочент кафедри української мови Дрогобицького державного педагогічного університету імені Івана Франка (Україна, Дрогобич) mishchuk_u@ukr.net

\title{
НІМЕЦЬКЕ ПОЧАТКОВЕ ШКІЛЬНИЦТВО НА ДРОГОБИЧЧИНІ У РОКИ НАЦИСТСЬКОї ОКУПАЦІї (1941 - 1944) ${ }^{1}$
}

У статті розкрито становище німецьького початкового икільництва на Дрогобиччині у 1941 1944 р. На основі документів німецьких окупаційних органів управління освітою розкрито формування шкільної мережі, кількісний і національний склад вчителів, динаміку учнівського контингенту, організачію навчально-виховного прочесу, рівень матеріально-фінансового забезпечення німецьких початкових шкіл. Дослідження охоплює територію Дрогобицької області УРСР, яка під час німецької окупацї була розподілена між галицьким та краківським дистриктами Генеральної Губернії.

Ключові слова: німецькі початкові школи, Дрогобиччина, нацистська окупачія, освітня політика.

Лim. 26.

Mykola HALIV,

PhD (Education), Associate Professor of the Department of History of Ukraine of Drohobych Ivan Franko State Pedagogical University (Ukraine,Drohobych) halivm@yahoo.com

Ulyana HALIV, PhD (Philology), Associate Professor of the Department of Ukrainian Language of Drohobych Ivan Franko State Pedagogical University (Ukraine,Drohobych) mishchuk_u@ukr.net

\section{GERMAN PRIMARY SCHOOLING IN DROHOBYCH REGION IN THE YEARS OF NAZI OCCUPATION (1941 - 1944)}

The article describes the situation of the German elementary school in Drohobych region in 1941 - 1944. Based on the documents of the German occupational authorities of education, the formation of the school network, the number and nationality of teachers, the dynamics of the pupils contingent, the organization of the educational process, the level of material and financial provision of the German elementary schools are researched. The study covers the territory of the Drohobych region of the Ukrainian SSR, which, during the German occupation, was divided between Galician and Krakow districts of the General Province. It was found that the formation of German elementary schools in the occupied Drohobych region occurred in places of compact residence of the Germans: the former Austrian colonies and the city-center areas. In the Drohobych region there were almost three dozens of German elementary schools. They were distinguished by a small number of teachers (approximately 50 people) and pupils (up to 1,500, most of whom were folksodoych). These schools, in comparison with the Ukrainian and Polish schools, received significant support from the authorities, in particular, the financial ones. However, in the wake of the war, funding for schools, including German ones, was unsatisfactory. With the approach of the front, German-language educational institutions ceased to exist and were not restored by the Soviet authorities after the war.

Key words: German elementary schools, Drohobych region, Nazi occupation, educational policy.

Ref. 26.

${ }^{1}$ Публікація містить результати досліджень, проведених при грантовій підтримці Держаного фонду фундаментальних досліджень за конкурсним проектом Ф77/80 - 2017. 
Николай ГАЛИВ,

кандидат педагогических наук, доиент, доиент кафедры истории Украинь Дрогобычского государственного педагогического университета имени Ивана Франко (Украина, Дрогобыч) halivm@yahoo.com

Ульяна ГАЛИВ, кандидат филологических наук, дочент кафедры украинского языка Дрогобычского государственного педагогического университета имени Ивана Франко (Украина, Дрогобыч) mishchuk_u@ukr.net

\section{НЕМЕЦКИЕ НАЧАЛЬНЫЕ ШКОЛЫ НА ДРОГОБЫЧЧИНЕ В ГОДЫ НАЦИСТСКОЙ ОККУПАЦИИ (1941 - 1944)}

В статье раскрыто положение немецких начальных школ на Дрогобыччине в 1941 - 1944 г2. На основе документов немецких оккупачионных органов управления образованием раскрыто формирования школьной сети, количественный и национальный состав учителей, динамику ученического контингента, организацию учебно-воспитательного процесса, уровень материально-финансового обеспечения немецких начальных школ. Исследование охватывает территорию Дрогобычской области УССР, которая во время немеикой оккупации была распределена между галииким и краковским дистриктами Генеральной Губернии.

Ключевые слова: немечкие начальные школь, Дрогобыччина, начистская оккупация, образовательная политика.

Лum. 26.

Постановка проблеми. У сучасних реаліях України зростає суспільний та науковий інтерес до складних, часто суперечливих подій Другої світової війни. Історики намагаються об'єктивно, різнобічно і глибоко висвітлити різноманітні аспекти згаданої проблеми, зокрема значну увагу присвячують специфічній й подекуди дуже хаотичній етнополітиці нацистського режиму в Україні (1941 - 1944). Помітне місце у їхніх наукових пошуках займає дослідження системи освіти різних окупованих регіонів України, підходи окупаційних властей до організації шкільництва для представників різних національностей. У цьому контексті актуальним є й з'ясування становища шкільництва етнічних груп Дрогобиччини окресленого періоду.

Аналіз останніх досліджень. Освітне життя різних окупованих регіонів України досліджують В. Гінда (Житомирщина), П. Добров та М. Бистра (Донбас), Л. Задорожна (Дніпропетровщина), Б. Сржабкова (терени рейхскомісаріату «Україна») та ін. Шкільництву західноукраїнського регіону років окупації присвячені дослідження Н. Антонюк [1], О. Луцького [16], Г. Стефанюк [20], М. Галіва [3-8]. Однак у них здебільшого висвітлюється становище української школи. Діяльність же польського шкільництва в роки Другої світової війни розглянуто, зокрема, у працях польських учених Г. Грицюка [21], Й. Красуського [22], Є. Круля [23], П. Маєвського [24], П. Матусяка [25], Й. Свєбоди [26] та окремих українських авторів [5]. На жаль, майже немає досліджень стану німецьких освітніх установ на західноукраїнських землях у добу нацистського окупаційного режиму.

Мета статті - проаналізувати становище німецького початкового шкільництва на Дрогобиччині у 1941 - 1944 р. за такими складовими: 1) шкільна мережа; 2) педагогічні кадри; 3) учнівський контингент; 4) навчально-виховний процес; 5) рівень матеріального забезпечення шкіл. Зауважимо, що географічні межі дослідження охоплюють територію так званої Дрогобицької області УРСР, яка під час німецької окупації була розподілена між галицьким (Дрогобицька, Стрийська, Самбірська округи, частина округи Львів-повіт) та краківським (частина Перемишльської округи з містами Добромиль та Хирів) дистриктами Генеральної Губернії (далі - ГГ). 
Виклад основного матеріалу. Нацистська політика у сфері освіти на окупованих землях Східної Галичини вирізнялася виразною диференціацією за національною ознакою. Попри надання дозволу на відкриття початкових шкіл для українців і поляків, влада організовувала й німецькі школи, які особливо толерувала та підтримувала. Після приєднання Східної Галичини до Генеральної губернії німецька влада поступово підпорядкувала собі систему освіти, визначила початок навчального року на 1 жовтня 1941 р. і відновила колишню польську структуру триступеневого народного шкільництва. Ступінь початкової школи залежав від кількості дітей шкільного віку: наявність менше 120 дітей передбачала утворення школи I ступеня (1-4 класи), 120-220 дітей - школи II ступеня (1-6 класи), понад 220 дітей шкільного віку - школи III ступеня (1-7 класи). Також за польським зразком встановлювався шкільний вік - 7-14 років, тож 1941 р. школи повинні були відвідувати діти 1927 - 1934 років народження [17, 1].

Значна увага німецькими властями (урядом галицького дистрикту та крейсшульратами в округах) присвячувалася німецькому початковому шкільництву. За час радянського управління краєм (1939 - 1941), як відомо, не було створено жодної школи з німецькою мовою навчання. Й це попри те, що традиція німецького початкового шкільництва тут сягала кінця XVIII початку XIX ст., коли австрійські колоністи розбудовували свої поселення на галицьких землях. Тож після встановлення окупаційного режиму для місцевих дітей-фольксдойчів, російських німців (russlanddeutschen), а також поодиноких дітей-рейхснімців, що прибули разом із батьками з Німеччини, почали створювати школи, зокрема й на Дрогобиччині.

На жаль, даних про мережу німещьких шкіл у 1941/42 навч. році майже немає. Згідно 3 даними шульамту, в Дрогобицькій окрузі на 8 травня 1942 р. діяло три німецькі школи: у Дрогобичі, Бориславі та Стебнику [12, 93 - 93 зв]. Зауважимо, що школу в Бориславі було відкрито власне в травні 1942 р. як однокласну $[12,94]$, однак з часом іï перетворено на чотирикласну, причому найбільшу з усіх за кількістю учнів. На той час уже велася підготовка щодо відкриття німецької школи в селі Нейдорф, де 18 дітей німецького походження відвідували польську школу [12, 93-93 зв]. Тож наступного 1942/43 навч. року в Дрогобицькій окрузі діяли чотири німецькі школи: в Дрогобичі та Бориславі - чотирикласні, Стебнику та Нейдорфі - однокласні [12, 87]. 3 вересня 1943 р. відкрито німецькі школи і в Трускавці та Кьонігсау [12, 158].

У Самбірській окрузі на 31 травня 1943 р. працювало сім німецьких народних шкіл: дві в Самборі, по одній у Кайзерсдорфі, Надбергу, Кранцбергу, Борині, Розлучі [9, 67]. Уже на 15 вересня 1943 р. там налічувалося вісім шкіл [12, 59, 81]. Більш чисельна за кількістю населення Стрийська округа на травень - червень 1943 р. містила 12 німецьких шкіл у містах Стрий, Сколе, Ходорів, Журавно, селах Болехів, Синевідсько Вижне, Дроговичі, Корнелівка, Гельсендорф, Махлинець, Нове Село, Брігідау. Майже половина з них призначалася для поселень російських німців, зокрема у Брігідау, Гельсендорфі, Махлинці, Новому Селі, Корнелівці, де школи відкрили у 1943 р. [15, 27].

Після об’єднання Самбірської та Дрогобицької округ (у другій половині 1943 р.) число шкіл дещо зросло. Як свідчать документи Дрогобицького шульамту, на 20 травня 1944 р. там діяло 15 німецьких шкіл (Борислав, Дрогобич, Йозефсберг, Кьонігсау, Нейдорф, Стебник, Турка, Угартсберг, Бориня, Кайзерсдорф, Кранцберг, Самбір, Розлуч, Воля Коблянська, Трускавець) $[12,158]$.

Загалом на теренах Дрогобиччини, Самбірщини та Стрийщини у 1943/44 навч. році існувало приблизно 27 німецьких шкіл. Ще одна німецька початкова школа працювала в Перемишлі $[26,187]$.

Учительські кадри німецьких шкіл формувалися переважно з фольксдойчів, інколи російських німців та рейхснімців. Щоправда, не всі фольксдойчі працювали винятково в німецьких школах. Так, на 31 травня 1943 р. у Самбірській окрузі працювали 22 вчителі-фольксдойчі, 3 них частина у польських (Дубляни, Бісковичі, Сусідовичі, Чуква, Надиби, Самборі) та українських народних школах (Бараничі, Ляшки Муровані, Воля Коблянська) [9, 67]. На Дрогобиччині майже всі педагоги-фольксдойчі працювали в ненімецьких школах. Зокрема, у школах Дрогобича вчителювали Ядвіга Лобос, Ольга Гіммель. Російські ж німці займали вчительські 
посади в німецьких школах Кьонігсау (Вєра Покровська), Трускавця (Марія Енгельгардт), Нейдорфа (Розалія Брейтенбюхер), Угартсберга (Едвард Пельц) [11, 22].

Загалом вчителів німецьких шкіл налічувалося небагато. На Стрийщині в 12 німецьких школах у травні-червні 1943 р. працювали 26 педагогів, під опікою яких перебували 698 дітей [15, 27] (один вчитель - 27 учнів). У Самбірській окрузі станом на 15 вересня 1943 р. у восьми німецьких школах працювали 10 вчителів (по п’ять чоловіків і жінок), навчаючи 363 учнів (один вчитель - 36 учнів) $[12,59,81]$. Така ж кількість педагогів працювала в чотирьох німецьких школах Дрогобицької округи протягом 1942/43 навч. року [12, 87]. Оскільки вони навчали 387 учнів, то на одного вчителя припадало майже 39 школярів. У 1943/44 н.р. кількість німецьких шкіл в Дрогобицькій окрузі, до якої приєднано на Самбірщину, як згадувалося вище, зросла, а отже, збільшилася й чисельність учителів. Так, на 20 травня 1944 р. у 15 школах об'єднаних округ працювало 23 педагоги, навчаючи 777 учнів [15, 27] (1 педагог/33 школярів).

Завдяки тому, що до нашого часу дійшли окремі документи Дрогобицького шульамту, ми може більш детально охарактеризувати педагогічний склад певних німецьких шкіл, зокрема Бориславської. Зі звіту про огляд цієї школи від 4 травня 1943 р. дізнаємося, що першим іiі керівником була «фрау Пілінські» (Кароліна Вілінська). Улітку 1942 р. школу очолила Вільгеміна Трильовска, а восени того ж року до школи переведено вчителя Хуго Гейнза. У звіті дається характеристика цим вчителям: «Керівник школи Хуго Гейнз є професіоналом, до 1939 р. працював у німецькій приватній школі в Станіславі. Він винятково сумлінний, старанний, усвідомлює свій обов'язок і віддає усі свої сили шкільній праці. Він має великий вплив на учнів, відносини з учителями є дружними. Пані Пілінскі вчителювала до 1939 р. у польській народній школі. Вільно володіє німецькою мовою, старанна і володіє доброю педагогічною майстерністю. Навчаючи письма, багато проводить життєвого навчання, яке доступне для дітей. У навчанні використовує прямий, безпосередній метод і отримує навчальний та виховний успіх. Пані Трильовскі до 1939 р. працювала тільки в ненімецьких школах, отримала освіту в польському вчительському інституті, вільно володіє німецькою мовою, добре підготовлена. Також отримує успіхи в навчанні, є сумлінною і працьовитою» $[12,94]$.

Для підвищення професійної кваліфікації для німецьких вчителів часто проводилися різноманітні курси. Особливу увагу приділяли мовній підготовці вчителів, передовсім фольксдойчів. Так, 1943 року у Стрию відбулися курси для вчителів-фольксдойчів (16 осіб зі Стрийської округи та 6 із Долинського повіту), метою яких було подолання їх мовного дефіциту, методична підготовка та «політичне виправлення в націонал-соціалістичному дусі» [15, 27-27 зв].

Німецькі власті часто вдавалися до переведення вчителів з інших регіонів ГГ задля заповнення вакансій у місцевих німецьких школах. До шкіл російських німців, що постали в Брігідау, Гельсендорфі, Махлинці, Новому Селі, Корнелівці на Стрийщині, 14 липня 1943 р. було скеровано 14 учителів-рейхснімців з Нижнього Дунаю (Niederdonau, Nieder-Donau). Щоправда, п’ять 3 них скеровано на працю до Стрийської німецької школи, один - до табору переселенців для ведення курсів німецької мови, решту - власне до нововідкритих шкіл в Бригідау, Корнелівці, Гельсендорфі, Махлинці і Новому Селі [15, 27-27 зв].

Загалом, на Дрогобиччині, Самбірщині та Стрийщині у 1943 - 1944 рр. в німецьких школах працювали 49 - 51 педагог. Порівняно з українським і польським, німецьке шкільництво не відчувало такої гострої кадрової проблеми, що пояснюється особливо уважним ставленням окупаційних властей до освітніх потреб власне німецького населення.

Німецькі початкові школи за кількістю учнів, зрозуміло, значно поступалися не лише українським, а й польським. Основну частину школярів становили діти-фольксдойчі, дещо менше було російських німців і зовсім мало рейхснімців.

Відповідно до списків німецьких дітей шкільного віку (1928 - 1935 рр. народження) Дрогобицької округи від 13 листопада 1941 р., найбільше їх мешкало у Бориславі та Дрогобичі (відповідно 74 і 72 особи). В інших населених пунктах округи налічувалося ще 124 дітей шкільного віку німецької національності, зокрема, у Нейдорфі - 17, Стебнику - 23, Підбужі - 4 [10, 1-2, $13,16-17,24]$. Отже, загалом в окрузі на той час було 270 дітей шкільного віку німецького походження, і поступово цей показник збільшувався. Уже на 5 травня 1942 р. у німецькій школі Дро- 
гобича навчалися 82 школярі: 49 учнів у класі фольксдойчів та 33 школярі у класі рейхснімців і фольксдойчів [10,30]. За даними крейсшульрату, на 8 травня 1942 р. цю ж школу відвідувало вже 87 дітей, з них «багато дітей фольксдойчів з повіту». На той час у Бориславській німецькій школі освіту здобувало 116 дітей, а в Нейдорфі нарахували 18 дітей німецького походження, i для них розпочали створювати школи [12, 93-93 зв].

Згідно з планом шульамту, на початку 1942/43 н.р. у чотирьох німецьких школах Дрогобицької округи мали навчатися 387 дітей, 3 них у чотирикласній школі Дрогобича - 152, чотирикласній школі Борислава - 164, однокласній школі Стебника - 44, однокласній школі Нейдорфа 27 учнів [12,87]. Проте у деяких школах цих показників не вдалося досягти (наприклад, у Бориславі на 4 травня 1943 р. навчалося 137 дітей фольксдойчів і один рейхснімець [12, 94]). 3 вересня 1943 р. відкрито німецькі школи у Трускавці та Кьонігсау. Першу з них на 15 вересня 1943 р. відвідували 16 дітей (6 фольксдойчів і 10 російських німців) [12, 67], другу на лютий 1944 р. - 10 дітей-фольксдойчів 1930 - 1931 років народження (Роза Зауфман, Лука Градельників, Фрідріх Нох, Георг Жолер, Броніслав Жвірнак, Ольга Грюндеман, Лідія Краус, Вільгеміна Леопольд, Ядвіга Жук, Міліна Жернікель) [9, 82].

Самбірська округа налічувала приблизно таку ж кількість учнів німецького походження. Так, на 15 вересня 1943 р. у восьми німецьких школах Самбірщини навчалися 363 учні [12, 59, 81]. Найбільшою була школа в Самборі, де на той час здобували освіту 113 дітей, з них 13 рейхснімців, 61 фольксдойчів і 39 російських німців (у 1-у класі - 42, 2-у - 16, 3-у (дві групи) - 24, 4-у (три групи) - 20 учнів [12, 69]. Після об’єднання Дрогобицької і Самбірської округ, як уже згадувалося, загальна кількість німецьких шкіл у новому територіально-адміністративному утворенні сягнула 15 . На 20 травня 1944 р. там здобували освіту приблизно 760 - 777 учнів [12, 158]. Показово, що, попри значне загальне число учнів, в окремих школах їхня кількість дещо знизилася порівняно з 1942/43 н.р. і навіть з початком 1943/44-го. Для прикладу, в німецькій школі Дрогобича залишилися 105 учнів, Борислава - 122 (або 116), Самбора - 99, Стебника $12[12,158]$. Відчувалося наближення фронту, і це, звісно, не могло не позначитися на чисельності учнівського контингенту.

Про учнів німецьких шкіл Стрийщини залишилося доволі мало джерельного матеріалу. Відомо, однак, що на червень-липень 1943 р. у 12 німецьких народних школах Стрийської округи навчалися 698 учнів. Найбільше дітей відвідувало школу у Стрию (144 школярі), Бригідау (87), Сколе (77) $[15,27]$. Зауважимо, що у школах поселень Брігідау, Гельсендорф, Махлинець, Нове Село та Корнелівка навчалися, переважно, діти російських німців.

Таким чином, кількість учнів німецьких шкіл на теренах трьох округ у 1943 - 1944 рр. становила приблизно 1460 осіб (19 - 20 \% загального числа німців і фольксдойчів).

Організація навчально-виховного процесу народних шкіл порівняно 3 попереднім (радянським) періодом також зазнала суттєвих змін. Шкільний рік було поділено на три періоди: перший тривав з вересня до грудня, другий - від січня до березня, третій - із квітня до червня. Кожен такий «триместр» закінчувався «класифікацією» (підбиттям підсумків успішності учнів), а також «вивідною конференцією», на якій батьків та опікунів повідомляли про результати «класифікації». Наприкінці першого і третього періодів видавалися свідоцтва 3 оцінкою. Зимові канікули у 1941/42 навч. році тривали 15 днів (з 6 до 20 січня включно), Великодні - 7. Крім того, 4 вільні дні припадало на Зелені свята. «Великі ферії» (літні канікули) тривали 62 дні - від 1 липня до 31 серпня включно [2, 34; 18, 3; 19, 4].

У німецьких школах, звісно, не вивчали ні польську, ні українську мови, а головним завданням було вивчення німецької. Уже згадувалося, що більшість учнів німецьких шкіл складали діти-фольксдойчі. Вони переважно не дуже добре володіли німецькою мовою. За даними шульамту (8.5.1942р.), діти німецьких шкіл Дрогобицької округи поза межами освітнього закладу спілкувалися здебільшого польською мовою [12, 93-93 зв]. Під час перевірки чотирикласної німецької школи у Бориславі шкільний інспектор занотував, зокрема, таке: «Діти, за свідченням вчителів, поза школою розмовляють польською мовою, тому що більшість їх батьків розмовляють німецькою ледь-ледь» $[12,94]$. Тож учителів орієнтували на «цілеспрямоване розширення» мовного запасу учнів. Загалом у цій справі вдавалося досягати певних успіхів, 
які шкільними інспекторами пояснювалися тим, «що і всі [німецькі] школи округи дуже малі» [12, 93-93 зв]. «Значні успіхи» в оволодінні мовою зафіксували в травні 1943 р. у вищезгаданій Бориславській німецькій школі, де ще на початку 1942/43 навч. року «дуже мало дітей самостійно розмовляли німецькою мовою» $[12,94]$. Крім того, учні німецьких шкіл майже 3 кожного предмету змушені були вивчати й специфічні теми: «Націоналсоціалізм», «Родознавство, расовість, спадковість», «Символіка» тощо $[14,10]$. Причому навчальний план не передбачав вивчення релігії.

I влада, і громадські організації надавали вчителям певні методичні розробки з різних предметів. Для вчителів німецьких шкіл основним «методичним порадником» був журнал «Німецька народна школа у Генеральній губернії». Очільник головного відділу науки і навчаня уряду ГГ А. Вацке наголошував на необхідності його безкоштовного розповсюдження серед усіх педагогів німецьких шкіл. Щоправда, на червень 1942 р. в галицькому дистрикті не вдалося організувати забезпечення педагогів згаданим виданням, що викликало незадоволення урядовців від освіти. «Я надаю великого значення тому, щоб зміст журналу докладно та грунтовно обговорювався при слушних нагодах (на нарадах в окружного шкільного радника, при діловій співпраці, на засіданнях учительських колективів і т. д.)» $[14,12],-$ писав А. Вацке у телеграмі Стрийському крейсгауптману (17.06.1942р.).

Виховання учнів німецьких шкіл здійснювалося на засадах націонал-соціалістичної ідеології, теорії расової вищості, відданості фюрерові і рейху тощо. Ще 20 листопада 1940 р. міністр освіти і виховання Третього рейху Руст, окреслюючи завдання німецької школи, заявив: «Справи плану навчання можемо спокійно відкласти у бік [...] Часи педагогічних енциклопедій минули. Мусимо молодь так виховати, аби продовжувала й надалі справу Гітлера» [25, 227]. Молодь передовсім намагалися залучити до нацистської молодіжної організації «Гітлерюгенд». Так, головний відділ науки і навчання уряду ГГ уже 12 січня 1942 р. надіслав розпорядження Стрийському шульамту охопити юнаків-фольксдойчів всієї округи цією структурою $[14,3]$.

Матеріальне забезпечення німецького шкільництва було помітно кращим, порівняно з українським чи польським. Забезпечення приміщеннями німецьких шкіл, звісно, було кращим, ніж українських та польських. Так, на 15 вересня 1943 р. німецька однокласна школа Трускавця володіла трьома класними приміщеннями, трьома кімнатами для вчителів, однією кухнею. Площа класних кімнат сягала в середньому 42 кв.м., а шкільного двору - 2924 кв.м. [12, 67]. На жаль, у документах рідко вказується розмір земельного наділу, що надавався вчителям. Відомо, однак, що німецьким педагогам, яких призначили працювати до німецьких шкіл у Брігідау, Гельсендорфі, Махлинці, Новому Селі, Корнелівці (Стрийщина), було виділено 2-3 га землі $[15,27$ зв].

Архівні документи зберегли до нашого часу інформацію про фінансове забезпечення українських, польських і німецьких шкіл. Доволі цікаву інформацію містить проект бюджету Дрогобича на 1942/43 бюджетний рік (від 1 квітня до 31 березня). Так, на сім народних шкіл міська управа передбачила 86270 зл.: німецька школа - 12874, українська школа № 1 - 9245, українська школа № 2 - 11674, українська школа № 3 - 9387, польська школа № 4 - 20461, польська школа № 5 - 10495, польська школа № 6 - 12134 зл. Отже, для доволі невеликої за кількістю учнів та вчителів німецької школи, порівняно з українськими школами № 1 і 3, проектувалося краще фінансування. Про прихильне ставлення до німецької школи свідчить хоча б той факт, що на забезпечення іiі учнів навчальними посібниками передбачалося 4000 зл., тобто більше, ніж на інші школи разом (майже 53 \% від загальної суми на цю статтю витрат) $[13,9]$.

В остаточно ухваленій управою Дрогобича редакції бюджету на 1942/43 фінансовий рік витрати на сім народних шкіл міста зросли на 400 зл., і становили 86670 зл. Проте бюджет, зрештою, виконано не було, що призвело до недофінансування народного шкільництва. Окружний шкільний радник Дрогобиччини д-р Біляв уже в травні повідомляв відділ науки і навчання уряду дистрикту «Галіція» про відмову штадткомісара Дрогобича (з січня 1942 р. цю посаду обіймав Шюслер) фінансово підтримати навіть німецьку школу, мотивувавши це тим, що «місто не має для цього засобів» $[12,93$ зв]. Такий стан речей штовхав крейсшульрата просити гроші 
в уряду дистрикту на облаштування хоча б німецької школи у Дрогобичі, а також створення інтернату (бурси) для дітей-фольксдойчів з округи [12, 58-58 зв].

Незважаючи на наближення фронту у 1944 р., шкільні власті, спираючись на прохання керівників шкіл, продовжували складати кошториси на наступний навчальний рік. До нашого часу дійшла копія складеного у червні 1944 р. проекту бюджету німецької народної школи в Йозефсберзі на 1944/45 навч. рік (див. табл. 1). Цей документ добре ілюструє конкретні статті видатків на матеріальне забезпечення шкільного приміщення.

Таблиця 1. Проект бюджету німецької народної школи в Йозефсберзі на 1944/45 н.р.

\begin{tabular}{|c|c|c|c|}
\hline № & & Стаття витрат & Сума \\
\hline \multirow[t]{8}{*}{ I } & \multicolumn{2}{|r|}{ Ремонт шкільного будинку } & 12186 зл \\
\hline & 1 & Ремонт вікон & 1284 зл \\
\hline & 2 & Дрібний ремонт дверей & 1992 зл \\
\hline & 3 & Реконструкиія і ремонт печей & 4180 зл \\
\hline & 4 & Ремонт підлоги & 2330 зл \\
\hline & 5 & Внутрішня побілка будинку & 1000 зл \\
\hline & 6 & Ремонт даху і ринв & 600 зл \\
\hline & 7 & Ремонт теуалету & 800 зл \\
\hline \multirow[t]{3}{*}{ II } & \multicolumn{2}{|r|}{ Закупівля і ремонт інвентаря } & 4940 зл \\
\hline & 1 & Купівля 40 нових парт по 36 зл кожна & 1440 зл \\
\hline & 2 & Купівля меблів (столи, стільијі, класні дошки) & 3500 зл \\
\hline \multirow[t]{3}{*}{ III } & \multicolumn{2}{|r|}{ Закупівля навчальних посібників і літератури } & 5800 зл \\
\hline & 1 & Навчальні посібники & 2800 зл \\
\hline & 2 & Література для унів і учительської бібліотеки & 3000 зл \\
\hline \multirow[t]{3}{*}{ IV } & \multicolumn{2}{|r|}{ Спорудження спортивних майданчиків } & 2700 зл \\
\hline & 1 & Спорудження спортмайданчиків & 800 зл \\
\hline & 2 & Купівля спортивного інвентарю & 1900 зл \\
\hline \multirow[t]{5}{*}{ V } & \multicolumn{2}{|r|}{ Опалення і освітлення } & 6195 зл \\
\hline & 1 & Купівля 105 куб.м. дров за 17 зл. кожен & 1785 зл \\
\hline & 2 & Довезення дров & 1050 зл \\
\hline & 3 & Ремонт сараю для зберігання дров & 3000 зл \\
\hline & 4 & Освітлення у класах взимку & 300 зл \\
\hline \multirow[t]{3}{*}{ VI } & \multicolumn{2}{|r|}{ Оплата праці допоміжного персоналу } & 1560 зл \\
\hline & 1 & Прибиральничя (90 зл щеомісяияя) & 1080 зл \\
\hline & 2 & Куховарка (40 зл щчомісячя) & 480 зл \\
\hline \multirow[t]{3}{*}{ VII } & \multicolumn{2}{|r|}{ Інше } & 2500 зл \\
\hline & 1 & Купівля кухонного посуду & 2000 зл \\
\hline & 2 & Виготовлення шкільного герба & 500 зл \\
\hline & & ВСЬОГО & 35821 зл \\
\hline
\end{tabular}

Джерело: ДАЛО. - Ф. Р-1926. - Оп. 1. - Спр. 89. - Арк. 18-19.

Звісно, за таких умов забезпечення навчального процесу початкових шкіл необхідним інвентарем, приладдям, наочними посібниками тощо було або вкрай мізерним, або взагалі відсутнім. Навіть німецькі школи відчували потребу у шкільному інвентарі. Як випливає з повідомлення німецьких чиновників Стрийщини (червень 1943 р.), наявний у новостворених німецьких школах Бригідау, Махлинця, Гельсендорфа, Нового Села, Корнелівки інвентар був недостатнім, хоч дозволяв упорядковано здійснювати «шкільне виробництво» (навчальний процес) [15, 27 зв].

Постачання шкіл навчальною літературою також майже не здійснювалося. Звичайних букварів бракувало не лише українським та польським, а й німецьким школам. Хоч останні, звісно, постачалися краще - фірма «Леве», зокрема, надала німецьким школам Стрийщини не лише навчальні посібники, а й зошити, олівці тощо [15, 27 зв]. 
Освітніми властями були розроблені певні вимоги щодо впорядкування вчительських бібліотек німецьких шкіл, які відомі нам з інструкції стрийського окружного шкільного радника для німецької школи у Стрию (22.05.1942р.). Згідно з нею, книги вчительської бібліотеки потрібно впорядкувати за відповідними розділами та позначити такими буквами у бібліографічній картотеці: А - Виховні та навчальні дисципліни. Історія виховання та викладання. Психологія та допоміжні науки педагогіки; NS - Націонал-соціалізм; D - Викладання німецької мови, читання, письмо; G - Історія; E - Географія, краєзнавство; N - Природничі науки; F - Наука про сім'ю (родину), наука про расу, наука про рід; M - Математика; S - Співи, музика; Т - Спортивна гімнастика, спорт та ігри; $\mathrm{Z}$ - Малювання та естетичне виховання; W - Праця, трудове навчання та наука про домашнє господарство; Sch - Організація Шкільного (навчального) процесу; V - Різне [14, 10].

Крім того, крейсшульрат рекомендував запровадити облікові картки книжок із вказівкою імені автора, назви книжки та бібліотечного шифру відповідного розділу, а також оформити читацький квиток кожному читачеві. 3 приводу керівництва та адміністрування вчительськими бібліотеками він радив орієнтуватися на працю Г. Штайнера «Бібліотека для вчителів» [14, 10 зв].

Певного значення влада надавала й налагодженню харчування учнів у школах. Особлива увага, звісно, присвячувалася німецьким дітям. У звіті дрогобицького крейсшульрата від 8 травня 1942 р. зазначалося, що забезпечення харчування дітей німецької національності є центральним завданням шкіл. На той час вдалося організувати харчування усіх дітей-фольксдойчів у «змішаних школах» (мабуть, йшлося про україно- та польськомовні школи): вони отримували на сніданок молоко та хліб [12, 93-93 зв].

Висновки. Отже, утворення німецьких початкових шкіл на теренах окупованої Дрогобицької області відбулося у місцинах компактного проживання німців: колишніх австрійських колоніях та місті-центрі округи. Німецькі громади мали певну традицію початкового шкільництва ще з часів імперії Габсбургів, тож існування німецьких шкіл не було чимось винятковим у роки нацистської війни. Загалом на Дрогобиччині постало майже три десятки німецьких початкових шкіл. Проте вони вирізнялися незначною чисельністю вчителів (приблизно 50 осіб) та учнів (до 1,5 тис. осіб, більшість з яких були фольксдойчами). Ці школи, порівняно з українськими та польськими, отримували значну підтримку органів влади, зокрема матеріальну. Звісно, в умовах війни фінансування шкіл, у тому числі й німецьких, було незадовільним. 3 наближенням фронту німецькомовні заклади освіти припинили існування й не були відновлені радянськими властями після війни.

\section{СПИСОК ВИКОРИСТАНИХ ДЖЕРЕЛ І ЛІТЕРАТУРИ}

1. Антонюк Н. В. Українське культурне життя в Генеральній Губернії (1939- 1944 роки) / Н. В. Антонюк. - Львів, Б. в., 1997. -232 с.

2. Вісник Українського Центрального комітету. - 1942. - Ч. 1/27. - 1 січня. - С. 34.

3. Галів М. Народне (початкове) шкільництво Самбірщини в період німецької окупації (1941 1944 рр.) / М. Галів // Література Галицького Підгір'я кінця XIX - початку XX століття і процес національного відродження (3 нагоди 140-ї річниці від дня народження Івана Филипчака): Матеріали Міжнар. наук.-практ. конф. (Самбір - Дрогобич, 17 лютого 2011 р.). - Дрогобич: Коло, 2011. - С. 65-78.

4. Галів М. Народне (початкове) шкільництво Стрийщини у період німецької окупації (1941 - 1944) / М. Галів // Збірник наукових праць молодих учених Дрогобицького державного педагогічного університету імені Івана Франка. - Дрогобич, 2012. - Вип. І. - С. 372-383.

5. Галів М. Польське шкільництво на Дрогобиччині в період німецької окупації (1941 - 1944 pp.) / М. Галів // Fasciculi Musei Regionalis Brzozoviensis. - Brzozów: Wydawnictwo Muzeum Regionalnego im. Adama Fastnachta w Brzozowie, 2011. - Nr. 5. - S. 235-262.

6. Галів М. Українське і польське народне шкільництво на Дрогобиччині періоду німецької окупації (1941 - 1944): порівняльний аналіз / М. Галів // Україна-Польща: історична спадщина і суспільна свідомість: Зб. наук. праць. - Львів, 2010 - 2011. - Вип. 3 - 4. - С. 147-158.

7. Галів М. Українське шкільництво в дистрикті «Галіція» (1941 - 1944 рр.) / М. Галів // Людинознавчі студії: Збірник наукових праць ДДПУ. - Вип. 9. Педагогіка. - Дрогобич: Вимір, 2004. - С. 135-147. 
8. Галів М. Українське шкільництво на Дрогобиччині в час німецької окупації $1941-1944$ рp. / М. Галів // Літопис Бойківщини. - 2010. - Ч. 279(90). - С. 65-71.

9. Державний архів Львівської області (далі - ДАЛО). - Ф. Р-1926. - Оп. 1. - Спр. 2.

10. ДАЛО. - Ф. Р-1926. - Оп. 1. - Спр. 82.

11. ДАЛО. - Ф. Р-1926. - Оп. 1. - Спр. 86.

12. ДАЛО. - Ф. Р-1926. - Оп. 1. - Спр. 90.

13. ДАЛО. - Ф. Р-1951. - Оп. 1. - Спр. 151.

14. ДАЛО. - Ф. Р-1964. - Оп. 1. - Спр. 10.

15. ДАЛО. - Ф. Р-1964. - Оп. 1. - Спр. 19.

16. Луцький О. Українське культурне життя Галичини під час німецької окупації $1941-1944$ pp. / О. Луцький // Україна: культурна спадщина, національна свідомість, державність: Зб. наук. праць. - Львів, 1997. - Вип. 3-4. - С. 194- 225.

17. Напередодні навчального року // Самбірські вісті. - 1941. - Ч. 14. - 21 вересня. - С. 1.

18. Організація й поділ шкільного року // Львівські вісті. - 1942. - Ч. 3(127). - 4/5 січня. - С. 3.

19. Організація й поділ шкільного року // Стрийські вісті. - 1942. - № 6. -25 січня. - С. 4.

20. Стефанюк Г. В. Шкільництво в Західній Україні під час німецької окупації (1941 - 1944 рр.) / Г.В. Стефанюк: Дис... канд. іст. наук: 07.00.01. - Івано-Франківськ, 2004. - 215 с.

21. Hryciuk G. Polacy w Małopolsce Wshodniej wobec okupacji niemieckiej. Przyczynek do prób wprowadzenia «elastycznego kursu» w Dystrykcie Galicji w latach 1943 - 1944 / G. Hryciuk // Acta Universitatis Wratislaviensis: Historia, CXVI: Polska - Kresy - Polacy. Studia Historyczne. - Wrocław: Wydawnictwo Uniwersytetu Wrocławskiego, 1994. - S. 307-316.

22. Krasuski J. Tajne szkolnictwo polskie w okresie okupacji hitlerowskiej 1939 - 1945 / J. Krasuski. Wydanie drugie, rozszerone. - Warszawa: Państwowe Wydawnictwo Naukowe, 1977. - $411 \mathrm{~s}$.

23. Król E. C. Polityka hitlerowska wobec szkolnictwa polskiego na terenie Generalnej guberni (19391945) / E. C. Król. - Warszawa: Wydawnictwa Szkolne i Pedagogiczne, 1979. - 243 s.

24. Majewski P. Wojna i kultura: instytucje kultury polskiej w okupacyjnych realiach Generalnego Gubernatorstwa 1939 - 1945 / P. Majewski. - Warszawa: Trio, 2005. - 431 s.

25. Matusak P. Edukacja i kultura Polski Podziemnej 1939 - 1945 / P. Matusak. - Siedlce, 1997. - 562 s.

26. Świeboda J. Zarys historii tajnej oświaty w latach ocupacji hitlerowskiej w powiecie przemyskim / J. Świeboda // Rocznik komisji nauk pedagogicznych PAN. - 1976. - T. XIX: Materiały do dziejów oświaty w okresie ocupacji hitlerowskiej (1939 - 1945) na terenie podziemnego okręgu szkolnego krakowskiego. - Cz. X. S. 183-193.

\section{REFERENCES}

1. Antoniuk N. V. Ukrainske kulturne zhyttia v Heneralnii Hubernii (1939 - 1944 roky) / N. V. Antoniuk. - Lviv, B. v., 1997. - 232 s.

2. Visnyk Ukrainskoho Tsentralnoho komitetu. - 1942. - Ch. 1/27. - 1 sichnia. - S. 34.

3. Haliv M. Narodne (pochatkove) shkilnytstvo Sambirshchyny v period nimetskoi okupatsii (1941 1944 rr.) / M. Haliv // Literatura Halytskoho Pidhiria kintsia XIX - pochatku XX stolittia i protses natsionalnoho vidrodzhennia (Z nahody 140-yi richnytsi vid dnia narodzhennia Ivana Fylypchaka): Materialy Mizhnar. nauk.-prakt. konf. (Sambir - Drohobych, 17 liutoho 2011 r.). - Drohobych: Kolo, 2011. - S. 65-78.

4. Haliv M. Narodne (pochatkove) shkilnytstvo Stryishchyny u period nimetskoi okupatsii (1941 - 1944) / M. Haliv // Zbirnyk naukovykh prats molodykh uchenykh Drohobytskoho derzhavnoho pedahohichnoho universytetu imeni Ivana Franka. - Drohobych, 2012. - Vyp. I. - S. 372-383.

5. Haliv M. Polske shkilnytstvo na Drohobychchyni v period nimetskoi okupatsii $(1941-1944$ rr.) / M. Haliv // Fasciculi Musei Regionalis Brzozoviensis. - Brzozów: Wydawnictwo Muzeum Regionalnego im. Adama Fastnachta w Brzozowie, 2011. - Nr. 5. - S. 235-262.

6. Haliv M. Ukrainske i polske narodne shkilnytstvo na Drohobychchyni periodu nimetskoi okupatsii (1941 - 1944): porivnialnyi analiz / M. Haliv // Ukraina-Polshcha: istorychna spadshchyna i suspilna svidomist: Zb. nauk. prats. - Lviv, 2010 - 2011. - Vyp. 3 - 4. - S. 147-158.

7. Haliv M. Ukrainske shkilnytstvo v dystrykti «Galitsiia» (1941 - 1944 rr.) / M. Haliv // Liudynoznavchi studii: Zbirnyk naukovykh prats DDPU. - Vyp. 9. Pedahohika. - Drohobych: Vymir, 2004. - S. 135-147.

8. Haliv M. Ukrainske shkilnytstvo na Drohobychchyni v chas nimetskoi okupatsii 1941 - 1944 rr. / M. Haliv // Litopys Boikivshchyny. - 2010. - Ch. 279(90). - S. 65-71.

9. Derzhavnyi arkhiv Lvivskoi oblasti (dali - DALO). - F. R-1926. - Op. 1. - Spr. 2.

10. DALO. - F. R-1926. - Op. 1. - Spr. 82.

11. DALO. - F. R-1926. - Op. 1. - Spr. 86. 
12. DALO. - F. R-1926. - Op. 1. - Spr. 90.

13. DALO. - F. R-1951. - Op. 1. - Spr. 151.

14. DALO. - F. R-1964. - Op. 1. - Spr. 10.

15. DALO. - F. R-1964. - Op. 1. - Spr. 19.

16. Lutskyi O. Ukrainske kulturne zhyttia Halychyny pid chas nimetskoi okupatsii 1941 - 1944 rr. / O. Lutskyi // Ukraina: kulturna spadshchyna, natsionalna svidomist, derzhavnist: Zb. nauk. prats. - Lviv, 1997. Vyp. 3-4. - S. 194- 225.

17. Naperedodni navchalnoho roku // Sambirski visti. - 1941. - Ch. 14. -21 veresnia. - S. 1.

18. Orhanizatsiia y podil shkilnoho roku // Lvivski visti. - 1942. - Ch. 3(127). - 4/5 sichnia. - S. 3.

19. Orhanizatsiia y podil shkilnoho roku // Stryiski visti. - 1942. - № 6. -25 sichnia. - S. 4.

20. Stefaniuk H. V. Shkilnytstvo v Zakhidnii Ukraini pid chas nimetskoi okupatsii (1941 - 1944 rr.) / H.V. Stefaniuk: Dys... kand. ist. nauk: 07.00.01. - Ivano-Frankivsk, 2004. - 215 s.

21. Hryciuk G. Polacy w Małopolsce Wshodniej wobec okupacji niemieckiej. Przyczynek do prób wprowadzenia «elastycznego kursu» w Dystrykcie Galicji w latach 1943 - 1944 / G. Hryciuk // Acta Universitatis Wratislaviensis: Historia, CXVI: Polska - Kresy - Polacy. Studia Historyczne. - Wrocław: Wydawnictwo Uniwersytetu Wrocławskiego, 1994. - S. 307-316.

22. Krasuski J. Tajne szkolnictwo polskie w okresie okupacji hitlerowskiej 1939 - 1945 / J. Krasuski. Wydanie drugie, rozszerone. - Warszawa: Państwowe Wydawnictwo Naukowe, 1977. - 411 s.

23. Król E. C. Polityka hitlerowska wobec szkolnictwa polskiego na terenie Generalnej guberni (1939 1945) / E. C. Król. - Warszawa: Wydawnictwa Szkolne i Pedagogiczne, 1979. - 243 s.

24. Majewski P. Wojna i kultura: instytucje kultury polskiej w okupacyjnych realiach Generalnego Gubernatorstwa 1939 - 1945 / P. Majewski. - Warszawa: Trio, 2005. - 431 s.

25. Matusak P. Edukacja i kultura Polski Podziemnej 1939 - 1945 / P. Matusak. - Siedlce, 1997. - 562 s.

26. Świeboda J. Zarys historii tajnej oświaty w latach ocupacji hitlerowskiej w powiecie przemyskim / J. Świeboda // Rocznik komisji nauk pedagogicznych PAN. - 1976. - T. XIX: Materiały do dziejów oświaty w okresie ocupacji hitlerowskiej $(1939$ - 1945) na terenie podziemnego okręgu szkolnego krakowskiego. - Cz. X. S. 183-193.

Стаття надійшла до редакиії 10.09.2017 p. 